Dragan Djordjević ${ }^{*}$, Miodrag Smelcerović ${ }^{2}$, Snežana Urošević3 ${ }^{3}$ Suzana Djordjević ${ }^{2}$

${ }^{1}$ University of Nis, Faculty of Technology, Leskovac, Serbia,

${ }^{2}$ High technological and artistic vocational school Leskovac, Leskovac, Serbia, ${ }^{3}$ University of Belgrade, Technical Faculty in Bor, Bor, Serbia
Review paper

ISSN 0351-9465, E-ISSN 2466-2585

UDC:677/678.001.43.45

doi:10.5937/ZasMat1701094D

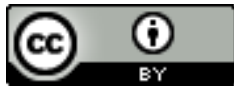

Zastita Materijala 58 (1)

$94-99$ (2017)

\title{
Textile protection through conservation and restoration
}

\begin{abstract}
It's not easy to keep the textile product for a long time or to isolate it from the environment, preventing destructive operation of the oxygen from the air or sunlight on one side and bacteria, fungi and insects on the other side. Cleaning is usually the first step of many processes in a protection through conservation work. It is also one of the most difficult operations undertaken when preserving textile artefacts. Since the benefits of cleaning usually outweigh the drawbacks are, another it can enhance the long-term preservation of textiles by removing soiling. Now it is recommended to avoid using mechanical methods for cleaning textile articles. In recent years, a number of new methods for textile cleaning. Laser has been considered to be a promising cleaning technique for artwork conservation due to the fact that laser is highly controllable and a monochromatic energy source which can remove the surface contaminants precisely and selectively. The advantage of laser cleaning is to remove the surface contamination layer by layer. Laser cleaning is an effective cleaning technique of textile artefacts since it provides a high degree of control that allows fragile objects with a considerable amount of surface detail to be effectively and safely cleaned. This study aims to evaluate the process of cleaning and preparation of significant textile items for the protection a longer period of time as well as using the laser cleaning technique for cleaning dirty, historic or archaeological textile materials and products as a precondition for lasting future protection.
\end{abstract}

Keywords: protection, conservation, restoration, textiles, cleaning, laser.

\section{INTRODUCTION}

Protection, and in this regard the conservation of textiles, representing a broad range of activities with the sole aim to increase the durability of textile materials and products as much as possible. Usually the term protection of textile broader concept than the more specific conservation of textiles.

Conservation - restoration, in many cases defined just as conservation (in German speaking countries the term restoration is still used), represents the profession or the activity which is dedicated to preservation of cultural heritage. Conservation activities include structure control, filing, the work on the cultural heritage item and preventive protection. All these activities are supported by scientific research and education [1, 2].

\footnotetext{
${ }^{*}$ Corresponding author: Dragan Djordjević

E-mail: drag_64@yahoo.com

Paper received: 22. 09. 2016.

Paper accepted: 30. 10. 2016.

Paper is available on the website: www.idk.org.rs/journal
}

The conservation of textile includes the entire range of treatment and processing of the valuable items, without tampering directly into the item's structure and changing its shape. Restorations is combined with conservation and represents the methods and procedures which are applied directly, in order to return a textile item or material into satisfactory form, where its original shape and preserved aesthetic, historical and physical integrity can be perceived. Conservationrestoration processing is often complex and it involves certain risks for the item [3-5].

In the last ten years there has been significant increase of application of the laser cleansing when conserving. From the pioneer work of John Asmus and his associates during the 1970s, laser technology has developed fast, so that laser cleansing became practical and confident procedure which provides the preserver high precision and control. The majority of the lasers cleansing works are directed towards the cleansing of the sculptures. The first research in textile conservation is done on silk and wool. Laser radiation at $1064 \mathrm{~nm}$ has been used for removing the dust and pencil traces on silk damask and silk 
velvet, while dust, fungi, starch pasta have been removed from the wool materials by applying laser radiation at $532 \mathrm{~nm}$. The examination of the cleaned surfaces, using electronic microscopy, does not reveal any damage of the fabric if the cleansing has been performed with the optimal level of total flux [6-9].

This work aims to show the laser application procedure in cleaning various textile materials within conservatory-restoration works.

\section{CLEANING OF THE TEXTILE BEFORE THE LASER APPEARANCE}

Before the first efficient laser devices have appeared, numerous radiation cleaning projects had to be done using non-laser sources due to its costs. Nowadays, with the development of the laser, its application can be provided at more favourable price. However, many modules of cleaning processes on large scale still require cheaper photons which cannot be produced by using commercially available lasers [10].

Before the highly-efficient commercial lasers were invented, standard light generators of high intensity for commercial and domestic usage had been xenon flash lamp (blinker, that is, photo flash). It has been used for decades when taking photos at high speeds, for signal devices, lithography... Some blinkers could produce dozens of megawatts of optic power (for example, for supplying colour laser). However, the blinker technology cannot produce focused and spectral laser clarity. On the other hand, systems of the blinkers are simpler, cheaper and more efficient from the laser of the same power and energy. It is particularly case in the shortwave end of the spectre, from green to ultraviolet colour [10].

\section{LASER APPLICATION IN TEXTILE CLEANSING WITH METAL THREADS}

Laser application can be seen when working with three-part hat from the museum collection in Bad Minder. It was necessary to clean the silver due to atmosphere corrosion. The hat was made from complicated brocade strip which treads were weaved with metal. Even in the old times, this item was more or less worn away due to cleaning, which led to creation of the thick layer of silver sulphide on the surface, and made the precious metal completely black. Using Nd:YAG laser, the brocade strip were dry-cleaned with nitrogen jet (Fig. 1). The cleansing results were optimal; all the obstacles which regularly appear with the regular cleansing of the silver in combination with textile were eliminated [11].

The best results were achieved on the field number 45 , figure 1 . The material has been dry- cleaned with laser, and then rinsed with liquid ammonia, while the remains of the finishing matt red could be removed by using the cotton wool for cleaning the silver.

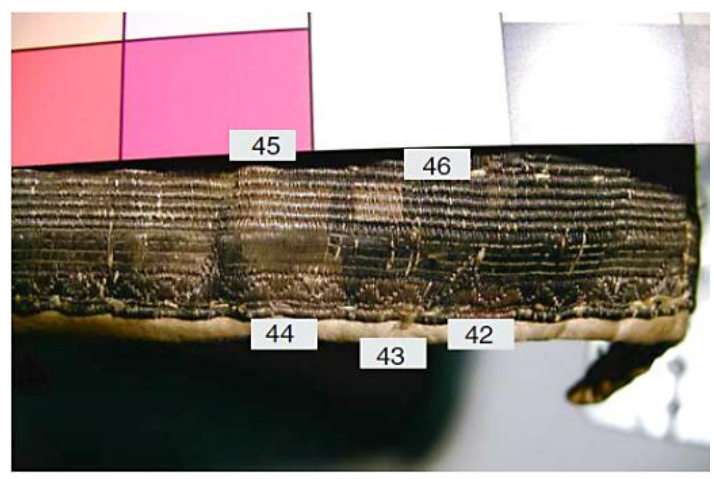

Figure 1. Three-piece silver bonnet from Bad Munder

\section{Slika 1. Trodelna srebrna kapa iz Bad Mindera}

The next case of laser application is cleaning the archaeological sample of corroded copper thread for embroidery on the textile received from the archaeological Egyptian wooden chest in Tanta Museum, Egypt (Fig. 2) [12].

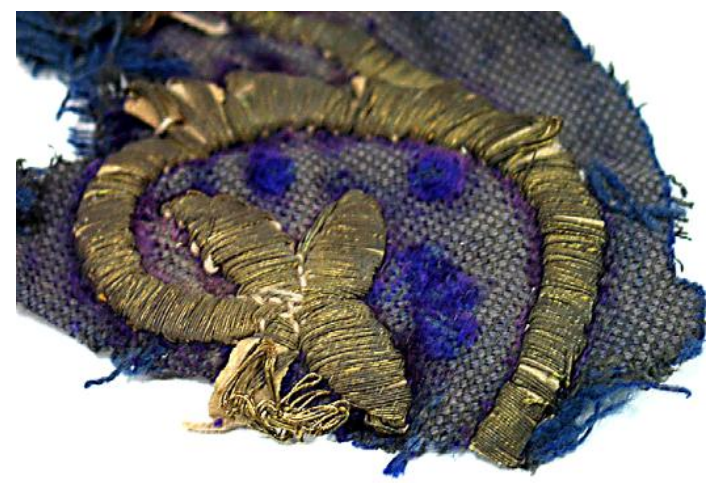

Figure 2. The archaeological Egyptian corroded copper threads at textile

Слика 2. Egipatske arheološke korodirale bakarne žice na tekstilu

Cleaning the samples of the copper threads has been done using Q-switched Nd:YAG laser (Brio, Quantel, France) which operates with secondary harmonic generator module (SHG) for obtaining laser pulses of $532 \mathrm{~nm}$ wavelength, 50 $\mathrm{mJ} / \mathrm{p}$ energy and maximum repetition speed of 20 $\mathrm{Hz}$. The total flux of the non-focused beam, which has been used for cleaning, was $0.25 \mathrm{~J} / \mathrm{cm}^{2}$, and it has been selected in order not to damage the threads since the similar researches have confirmed that the 532 laser radiation and total energy flux $<1 \mathrm{~J} / \mathrm{cm}^{2}$ make less damage the cellulose [12].

The results of the visual examination with optical microscope after laser cleaning show that the processed threads look much better. The most 
of the corrosion products which are showed in green, grey and blue colour were removed form the metal threads surface. They have become smooth and looked something like reddish-yellow, which is typical for copper (Fig. 3). The tarnished layers and layers of corrosion products on the surface have been successfully removed without any visible damage such as melting of the surface.

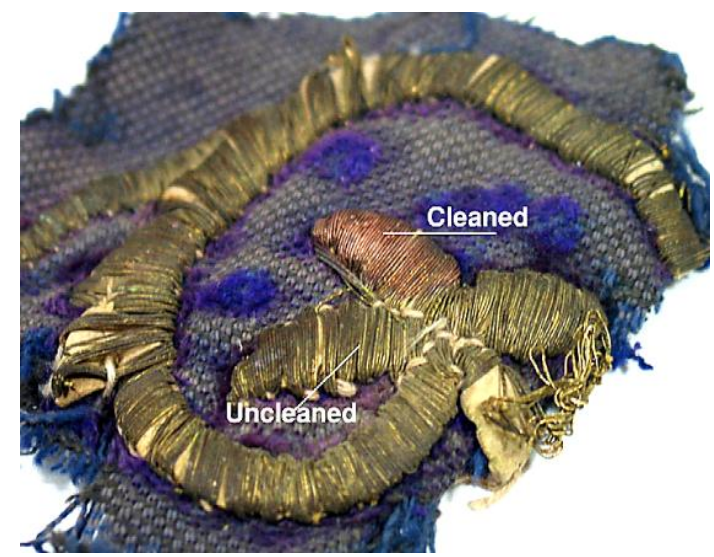

Figure 3. An optical microscopy image shows the surface appearance of the tested metal threads after the laser cleaning

Slika 3. Snimak optičkim mikroskopom izgleda površine testiranih metalnih žica posle čišćenja laserom

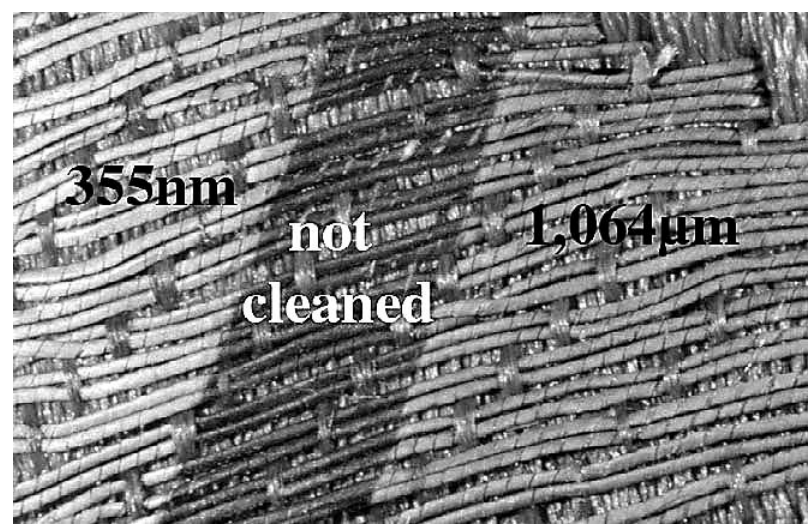

Figure 4. General view of the silver threads from a red satin fragment treated with different lasers (ultraviolet $(\lambda=355 \mathrm{~nm})$ and infrared

$(\lambda=1064 \mu \mathrm{m}))$ in comparison to an area that was not cleaned (for the UV experiment, $F=0.08 \mathrm{~J} / \mathrm{cm}^{2}$, $S_{\text {impact }}=0.53 \mathrm{~cm}^{2}, f=10 \mathrm{p} / \mathrm{s}$ for $5 \mathrm{~min}$; for the infrared experiment, $F=0.35 \mathrm{~J} / \mathrm{cm}^{2}, S_{\text {impact }}=$ $0.55 \mathrm{~cm}^{2}, f=10 \mathrm{p} / \mathrm{s}$ for $1.5 \mathrm{~min}$ )

Slika 4. Opšti izgled srebrnih niti iz fragmenta crvenog satena obrađenog različiti laserima, (ultraljubičasti $(\lambda=355 \mathrm{~nm}) \mathrm{i}$ infracrveni $(\lambda=1064$ um)) u poređenju sa površinom koja nije čišćena (not cleaned) (za UV eksperiment, $F=0,08 \mathrm{~J} / \mathrm{cm}^{2}$, $S_{\text {udar }}=0,53 \mathrm{~cm}^{2}, f=10 \mathrm{impuls} / \mathrm{s}$ u toku $5 \mathrm{~min} ; \mathrm{za}$ infracrveni eksperiment $F=0,35 \mathrm{~J} / \mathrm{cm}^{2}, S_{\text {udar }}=0,55$ $\mathrm{cm}^{2}, \mathrm{f}=10 \mathrm{impuls} / \mathrm{s}$ u toku 1,5 $\mathrm{min}$
Various lasers have been used: BMI 5000 laser Nd3:YAG, which emits infrared radiation $(\lambda=1064$ $\mathrm{cm}$ ) and Nd3+:YAG laser with the third overtone (obtained from optical isolation of the third overtone of the Nd3+:YAG laser), which emits ultraviolet radiation $(\lambda=355 \mu \mathrm{m})$. The second laser is equipped with toggle lever which can be positioned above the item when in horizontal position on the worktable. When applying Nd3+:YAG laser in infrared, the samples have to be positioned vertically in relation to laser beam [13].

The results obtained on laser $\mathrm{Nd} 3+$ :YAG with the third overtone were very interesting while those obtained on laser $\mathrm{Nd} 3+$ :YAG were less convincing (mat surface; Fig. 4). The total flux is much bigger, around $0.35 \mathrm{~J} / \mathrm{cm}^{2}$ for the same pulse frequency $(10 \mathrm{p} / \mathrm{s})$ but it has been applied only for a minute and a half.

\section{LASER APPLICATION IN TEXTILE CLEANING}

In the work of Belli and his associates, excimer laser has been examined (the type of UV laser) and its visible (with eye and electron microscope) impacts on textile material [14].

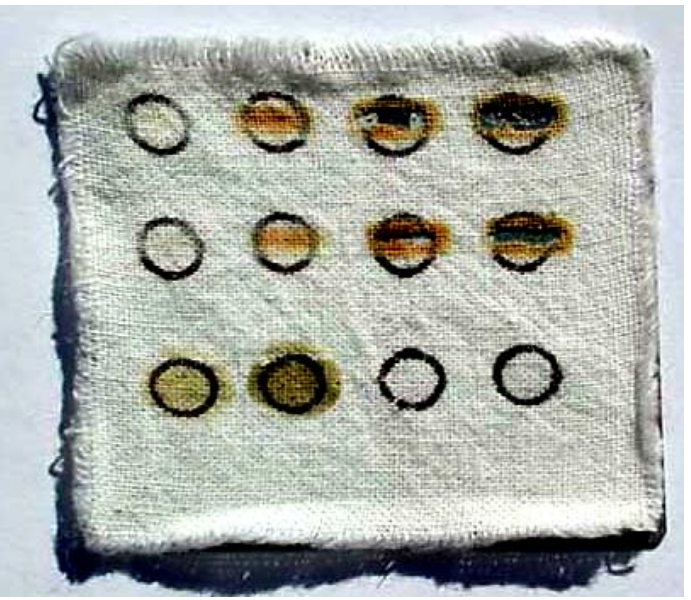

Figure 5. Cotton textiles after different conditions of irradiation (Upper row (from left to right):

10 pulses at $1400 \mathrm{~mJ} / \mathrm{cm}^{2}, 50$ pulses at $1400 \mathrm{~mJ} / \mathrm{cm}^{2}$, 200 pulses at $1400 \mathrm{~mJ} / \mathrm{cm}^{2}, 500$ pulses at $1400 \mathrm{~mJ} /$ $\mathrm{cm}^{2}$. Middle row (from left to right): 10 pulses at 1000 $\mathrm{mJ} / \mathrm{cm}^{2}, 50$ pulses at $1000 \mathrm{~mJ} / \mathrm{cm}^{2}, 200$ pulses at $1000 \mathrm{~mJ} / \mathrm{cm}^{2}, 500$ pulses at $1000 \mathrm{~mJ} / \mathrm{cm}^{2}$. Lower row (from left to right): 2000 pulses at $80 \mathrm{~mJ} / \mathrm{cm}^{2}, 5000$ pulses at $80 \mathrm{~mJ} / \mathrm{cm}^{2}$ )

Slika 5. Pamučni tekstilni materijali posle raznih uslova ozračivanja (Gornji red (sleva na desno): 10 impulsa na $1400 \mathrm{~mJ} / \mathrm{cm}^{2}, 50$ impulsa na 1400 $\mathrm{mJ} / \mathrm{cm}^{2}, 200$ impulsa na $1400 \mathrm{~mJ} / \mathrm{cm}^{2}, 500$ impulsa na $1400 \mathrm{~mJ} / \mathrm{cm}^{2}$. Srednji red (sleva na desno): 10 impulsa na $1000 \mathrm{~mJ} / \mathrm{cm}^{2}, 50$ impulsa na 1000 $\mathrm{mJ} / \mathrm{cm}^{2}, 200$ impulsa na $1000 \mathrm{~mJ} / \mathrm{cm}^{2}, 500$ impulsa na $1000 \mathrm{~mJ} / \mathrm{cm}^{2}$. Donji red (s leva na desno) 2000 impulsa na $80 \mathrm{~mJ} / \mathrm{cm}^{2}, 5000$ impulsa na $80 \mathrm{~mJ} / \mathrm{cm}^{2}$ ) 
Various textile materials have been analysed: wool, flax, cotton. Several radiation session have been performed: the laser source was $\mathrm{KrF}$ excimer laser, with a wavelength of $248 \mathrm{~nm}$ and pulse time of 20 ns. The chosen wavelength of $248 \mathrm{~nm}$ is based upon universal aims of the examination: to remove consolidate layers using strong ablation without the impact on the original textile material. The energy density, applied on the samples, was from 0.04 to $1.6 \mathrm{~J} / \mathrm{cm}^{2}$, while the number of pulses was from 1 to 10000 . For each energy density $(0.04 ; 0.08 ; 0.16 ; 0.32 ; 0.4 ; 0.6 ; 1.0 ; 1.2 ; 1.4$ and $1.6 \mathrm{~J} / \mathrm{cm}^{2}$ ) the number of pulses has been carefully chosen [14].

Visually, using the SEM, various types of damages have been noticed: tarnishing, yellowing, burnt parts, holes (Fig. 5). The results depended much upon the radiation intensity (energy density) and its duration (number of pulses).

Cleaning tests have been conducted on new plain weave cotton which has been deliberately stained (Fig. 6) in order to determine whether the efficient cleaning is possible with the total flux levels under the damage limits which have been determined for 1064, 532 and $266 \mathrm{~nm}$ (Fig. 7). Standard commercially prepared stained (coal and olive oil) cotton test fabric has been used [14].

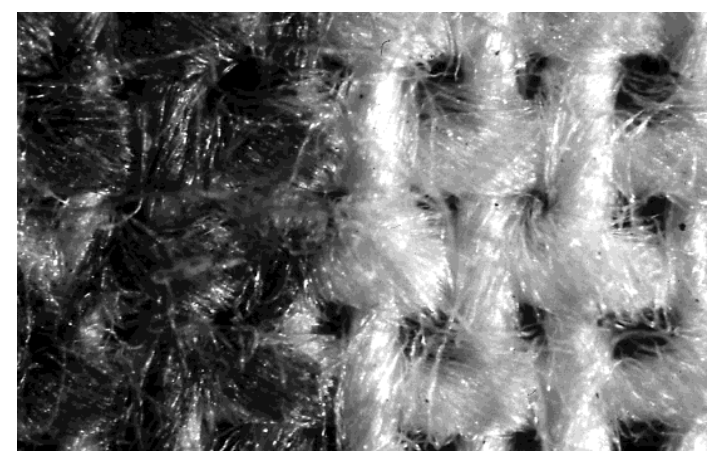

Figure 6. Area of new (soiled) cotton textile (approximately $4.5 \mathrm{~mm} \times 4 \mathrm{~mm}$ ) (Left side: artificially soiled; right side: clean)

Slika 6. Površina novog (zaprljanog) pamučnog tekstila (oko 4,5 $\mathrm{mm} \times 4 \mathrm{~mm}$ ) (Leva strana: veštački zaprljana; desna strana: čista)

40 times enlarged shots for synthetically stained cotton, after the processing, have revealed that the efficient (total dirt removal) and uniformly cleaning could have been achieved by using 1 $\mathrm{J} / \mathrm{cm}^{2}$ at $1064 \mathrm{~nm}$ and $1.1 \mathrm{~J} / \mathrm{cm}^{2}$ at $532 \mathrm{~nm}$ (Fig. 8) without causing the fibre damage. Small quantity of dirt was still present after the cleaning by applying $0.1 \mathrm{~J} / \mathrm{cm}^{2}$ at $266 \mathrm{~nm}$, but any damage or rupture of the textile structure has not been noticed at any examined wavelength (Fig. 9). The only drawback of synthetically stained test fabrics usage was the very perceivable colour change at $1064 \mathrm{~nm}$, as well as slight colour change at $532 \mathrm{~nm}$. This is the result of: a) staining the surface caused by heating the fibres due to thermal transfer from heated particles of dirt or b) remains of the dirt layer, probably oil component, which has changed the colour due to heating [14].

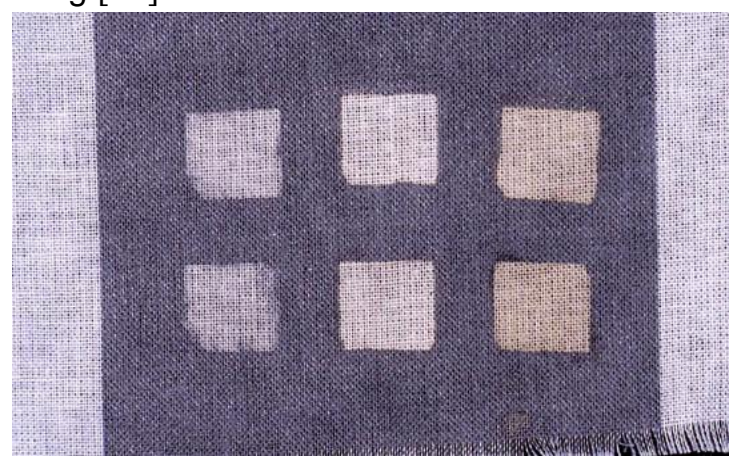

Figure 7. Laser test cleans on artificially soiled new cotton $(1.5 \mathrm{~cm} \times 1.5 \mathrm{~cm})$. Upper row (left to right): 1 ) $266 \mathrm{~nm}, 0.15 \mathrm{~J} / \mathrm{cm}^{2}$; 2) $532 \mathrm{~nm}, 3.2 \mathrm{~J} / \mathrm{cm}^{2}$; 3) 1064 $\mathrm{nm}, 2.7 \mathrm{~J} / \mathrm{cm}^{2}$. Lower row (left to right): 1) $266 \mathrm{~nm}, 0.1$ $\mathrm{J} / \mathrm{cm}^{2}$; 2) $532 \mathrm{~nm}, 1.1 \mathrm{~J} / \mathrm{cm}^{2}$; 3) $1064 \mathrm{~nm}, 1.0 \mathrm{~J} / \mathrm{cm}^{2}$

Slika 7. Testiranje čišćenja laserom vešački zaprljanog novog pamuka $(1,5 \mathrm{~cm} \times 1,5 \mathrm{~cm})$. Gornji red (s leva na desno): 1) $266 \mathrm{~nm}, 0,15 \mathrm{~J} / \mathrm{cm}^{2}$; 2) 532 $\mathrm{nm}, 3,2 \mathrm{~J} / \mathrm{cm}^{2}$; 3) $1064 \mathrm{~nm}, 2,7 \mathrm{~J} / \mathrm{cm}^{2}$. Donji red (s leva na desno): 1) $266 \mathrm{~nm}, 0,1 \mathrm{~J} / \mathrm{cm}^{2}$; 2) $532 \mathrm{~nm}, 1,1$ $\mathrm{J} / \mathrm{cm}^{2}$; 3) $1064 \mathrm{~nm}, 1,0 \mathrm{~J} / \mathrm{cm}^{2}$

Efficiency of the laser cleaning has been compared with three traditional conservation methods of textile cleaning: wet cleaning (the used solution was composed of non-ionic detergent (Synperonic N), anionic detergent (Arkopon T) and agents against deposition in soft water) and cleaning with organic solvent using industrial denatured alcohol (IMS) and white spirit (Table 1) [14].

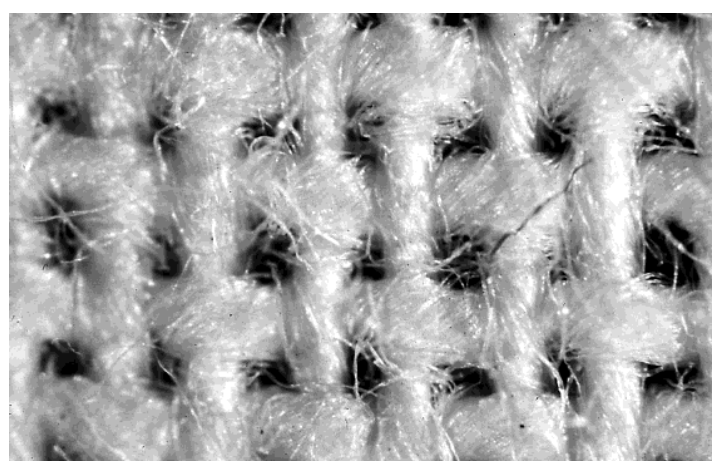

Figure 8. Area of artificially soiled cotton cleaned by $532 \mathrm{~nm}$ laser radiation at a fluence of $1.1 \mathrm{~J} / \mathrm{cm}^{2}$

(there are no signs of damage, similarly at $1064 \mathrm{~nm}, 1 \mathrm{~J} / \mathrm{cm}^{2}$ and $266 \mathrm{~nm}, 0.1 \mathrm{~J} / \mathrm{cm}^{2}$ )

Slika 8. Površina veštački zaprljanog pamuka očišćenog laserskim zračenjem na $532 \mathrm{~nm} i$ ukupnim fluksom od $1,1 \mathrm{~J} / \mathrm{cm}^{2}$ (nema znakova oštećenja, slično na $1064 \mathrm{~nm}, 1 \mathrm{~J} / \mathrm{cm}^{2}$ i $266 \mathrm{~nm}$, $0,1 \mathrm{~J} / \mathrm{cm}^{2}$ ) 

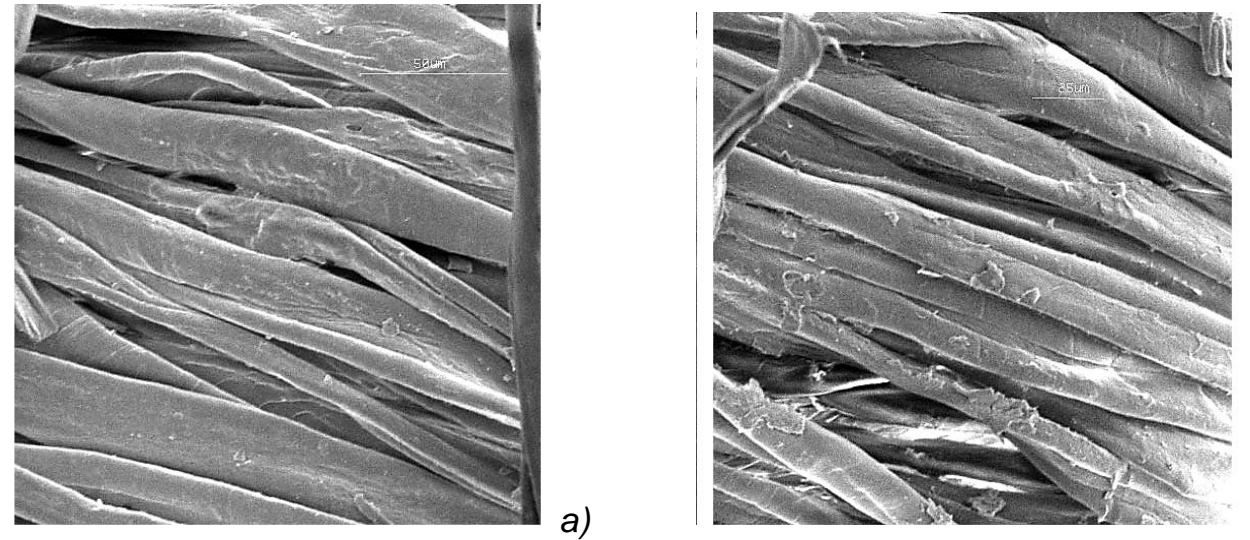

b)

Figure 9. Electron micrograph of new white cotton surface (area $175 \mu \mathrm{m} \times 175 \mu \mathrm{m}$ ) a) clean surface (not irradiated); b) artificially soiled surface cleaned by $532 \mathrm{~nm}$ laser radiation, $1.1 \mathrm{~J}: \mathrm{cm}^{2}$ (no signs of damage) Slika 9. Elektronski mikrografi površine novog belog pamuka (površina $175 \mu \mathrm{m} \times 175 \mu \mathrm{m}$ ) a) čista površina (nije ozračena); b) veštački zaprljana površina čišćena laserskim zračenjem sa $532 \mathrm{~nm}, 1,1 \mathrm{~J} / \mathrm{cm}^{2}$ (nema znakova oštećenja)

Table 1. Summary of laser cleaning, wet cleaning and organic solvent cleaning results Tabela 1. Pregled rezultata laserskog, mokrog i čišćenja organskim rastvaračima

\begin{tabular}{|l|c|c|c|}
\hline \multicolumn{1}{|c|}{ Procedure } & \multicolumn{1}{c|}{ Cleaning efficiency } & $\begin{array}{c}\text { Change of colour at } \\
\text { examined surface }\end{array}$ & $\begin{array}{c}\text { Surface rupture, fibre } \\
\text { damage at 40x }\end{array}$ \\
\hline Wet cleaning & Inefficient: slight removal of dirt & insignificant & Not visible \\
\hline Organic solvent (IMS) & Inefficient: slight removal of dirt & insignificant \\
\hline $\begin{array}{l}\text { Organic solvent } \\
\text { (white spirit) }\end{array}$ & Inefficient: slight removal of dirt & insignificant & Not visible \\
\hline $1064 \mathrm{~nm}, 1 \mathrm{~J} / \mathrm{cm}^{2}$ & Efficient: dirt is not visible & Dark grey to yellow-green & Not visible \\
\hline $532 \mathrm{~nm}, 1,1 \mathrm{~J} / \mathrm{cm}^{2}$ & Efficient: dirt is not visible & Dark grey to pale & $\begin{array}{c}\text { Small amount of fibre } \\
\text { damage is visible on } \\
\text { isolated surfaces }\end{array}$ \\
\hline $266 \mathrm{~nm}, 0,15 \mathrm{~J} / \mathrm{cm}^{2}$ & $\begin{array}{c}\text { Quite efficient: small amount of } \\
\text { dirt is visible }\end{array}$ & Dark grey to grey-white \\
\hline
\end{tabular}

Laser cleaning (at each wavelength) was more efficient at removing the dirt. Wet cleaning and cleaning with organic solvent could not make any noticeable changes in appearance of the solid surface. The results obtained at $532 \mathrm{~nm}$ were particularly promising since the removal of dirt was achieved without any fibre rupture or damage and with slight change in colour of textile surface. 2.5 $\mathrm{Hz}$ cleaning lasted about 45 minutes which is favorable compared to traditional methods. At 1064 $\mathrm{nm}$ cleaning was equally efficient but the change in colour was more perceivable. At $266 \mathrm{~nm}$ cleaning was less efficient and slight damage of fibres at several localised surfaces was visible $[9,14]$.

\section{CONCLUSION}

Protection through conservation of textile materials and products can be used as a leading idea in the special processing of textile (special finishing) where certain effects are created on textile and they refer to durability, longevity, protection from micro organisms and insects, sun and UV protection.
The item which is being restored is a unique artefact and inimitable piece of art or historically valuable creation. The understanding of its history, usage and epochal sequence of events which it has been exposed to, helps the restorer to make conclusion which type of dirt is on the textile/ textile item and choosing the best method and cleansing procedure. By combining precious knowledge of restorer and analytic methods, the best way for cleaning the historical textile item is being chosen. One should bear in mind that the simplest way in that process is also the most destructible and irreversible. Making compromises between the demands for total dirt removal and preserving the sensitive and degraded textile item is required from textile restorer.

Based on the presented information it seems that the laser cleaning has certain potential as a way of cleaning both new and naturally aged textile material. If the laser parameters, wavelength and total flux are carefully chosen, synthetic dirt can be removed form the textile without ruptures or damages in the way that is not possible to accomplish by using the wet cleaning methods or 
solvent cleaning methods. Laser cleaning is very precise and localised method which is suitable for extremely brittle surfaces.

It can be also said that laser cleaning is the most efficient procedure among the examined cleaning methods, on both archaeological corroded metal threads on textile fabrics and textile materials and products. It can be used safely for removing corroded layers without damaging metal strips and fibre cores. The laser cleaning procedure should solve the problems which regularly appear among other traditional cleaning procedures of metal or textile threads on museum textile.

\section{REFERENCES}

[1] E.Pye (2011) Caring for the past: Issues in conservation for archaeology and museums, James and James, London.

[2] F.Lennard, P.Ewer (2010) Textile conservation (Butterworth-Heinemann series in conservation and museology), Elsevier Ltd., London.

[3] A.M.Sackler (2005) Scientific examination of art: Modern techniques in conservation and analysis, The National Academies Press, Washington.

[4] M.V.Salvador (2005) Contemporary Theory of conservation, Elsevier/Butterworth Heinemann, London.

[5] E.Princi, S.Vicini, E.Pedemonte, V.Arrighi, I.McEwen (2005) New polymeric materials for paper and textile conservation. I. Synthesis and characterization of acrylic copolymers, Journal of Applied Polymer Science, 98(3), 1157-1164.
[6] C.W. Kan (2008) Impact on textile properties of polyester with laser, Optics\&Laser Technology, 40(1), 113-119.

[7] W.Wong, K.Chan, K.W.Yeung, K.S.Lau (2001) Chemical modification of poly(ethylene terephthalate) induced by laser treatment, Textile Resarch Journal, 71(2), 117-20.

[8] M.Cooper, J.Larson (1996) The use of laser cleaning to preserve patina on marble sculpture, The Conservator, 20, 28-35.

[9] U.Reichert (1998) Attempts at using laser technology for cleaning textiles; first experiences, Restauro, 104(6), 416-420.

[10] J.F.Asmus (2003) Non-laser light divestment in conservation and preservation, Journal of Cultural Heritage, 4(1), 56-58.

[11] A.Gervais, M.Meier, P.Mottner, G.Wiedemann, W.Conrad, G. Haber (2007) Cleaning historical metals: Performance of laser technology in monument preservation, lasers in the conservation of artworks, Springer Heidelberg, Berlin.

[12] O.Abdel-Kareem, M.A.Harith (2008) Evaluating the use of laser radiation in cleaning of copper embroidery threads on archaeological Egyptian textiles, Applied Surface Science, 254(18), 58545860.

[13] C.Degrigny, E.Tanguy, R.L.Gall, V.Zafiropulos, G.Marakis (2003) Laser cleaning of tarnished silver and copper threads in museum textiles, Journal of Cultural Heritage, 4(1), 152-156.

[14] R.Belli, A.Miotello, P.Mosaner, L.Toniutti (2005) Laser cleaning of ancient textiles, Applied Surface Science, 247(1-4), 369-372.

\section{IZVOD}

\section{ZAŠTITA TEKSTILA KROZ KONZERVACIJU I RESTAURACIJU}

Nije lako sačuvati tekstilni proizvod duže vreme ili ga izolovati od okoline, sprečavajući destruktivni utisaj kiseonika iz vazduha ili suncu sa jedne strane $i$ bakterija, gljivica i insekata sa druge. Čišćenje je obično prvi korak u mnogim procesima u zaštiti kroz konzervatorski rad. To je takođe jedna od najtežih operacija koja se preduzima radi čuvanja tekstilnih artefakata. Koristi od čišćenja obično prevazilaze nedostatke, a mogu i da pojačaju dugoročno čuvanje tekstila uklanjanjem prljavštine. Danas se preporučuje izbegavanje korišćenja mehaničkih metoda za čićenje tekstilnih predmeta. Poslednjih godina koriste se brojne nove metode za čišćenje tekstila. Smatra se da je laser perspektivan postupak čišćenja za konzervaciju umetničkih dela zbog činjenice da se laser može lako kontrolisati a izvor monohromatske energije može ukloniti površinska zaprljanja precizno i selektivno. Prednost čišćenja laserom je uklanjanje površinske nečistoće sloj po sloj. Lasersko čišćenje je efikasan postupak čišćenja tekstilnih artefakata pošto daje visok stepen kontrole $i$ omogućava efikasno $i$ bezbedno čišćenje lomljivih predmeta sa znatnim površinskim detaljima. Ovaj rad ima za cilj ocenjivanje procesa čišćenja i pripreme značajnih tekstilnih predmeta za zaštitu na duži vremenski period kao i primenu laserske tehnike za čišćenje prljavih, istorijskih ili arheoloških tekstilnih materijala i proizvoda, kao preduslova za trajniju zaštitu.

Ključne reči: zaštita, konzervacija, restauracija, tekstil, čišćenje, laser.

Pregledni rad

Rad primljen: 22. 09.2016.

Rad prihvaćen: 30. 10. 2016.

Rad je dostupan na sajtu: www.idk.org.rs/casopis

(c) 2017 Authors. Published by Inženjersko društvo za koroziju. This article is an open access article distributed under the terms and conditions of the Creative Commons Attribution 4.0 International license (https://creativecommons.org/licenses/by/4.0/) 